\title{
シカゴにおける建物高さ制限の変遷 (1893〜1902年)とその社会背景 \\ A STUDY ON THE TRANSITION OF BUILDING HEIGHT LIMITATIONS IN CHICAGO FROM 1893 TO 1902 AND ITS SOCIAL CONTEXT
}

\author{
坂本圭司*, 西村幸夫** \\ Kiyoshi SAKAMOTO and Yukio NISHIMURA
}

\begin{abstract}
No American city has changed its building height limitations as often as Chicago. The City Council of Chicago changed height limitations three times in 10 years from 1893. There also were a number of attempts to raise or reduce the limitations during the same period. This paper is to review the transition of building height limitations in Chicago from 1893 to 1902, and to clarify Chicago's own social context that caused such changes. Specifically, this paper is to focus on: 1) what were these changes and attempts like and what urban problems were behind these, 2) who took part in a series of discussion in conjunction with building height controls, and for what intentions they tried to change the limitations, and 3) what influence such instable limitations caused to the city and what problems were left after a series of changes.
\end{abstract}

Keywords: Chicago, Skyscraper, Building Height Limitation, City Council, and Real Estate シカゴ, スカイスクレーパー, 建物高さ制限, 市議会, 不動産

1. はじめに

(1)研究の目的

本論文は、20 世紀初頭のシカゴにおける、建物高さ制限の変遷と その社会背景を明らかにするものである。1 1893 年 3 月、当時世界で 最も高層建築物が建設されていたシカゴに、最高 130 フィート(約 $39 \mathrm{~m})$ とする建物高さ制限が初めて制定された。この制限はその後 1902 年に 260 フィートに引き上げられるまでの 10 年間に、合計 3 回変更され、さらに数々の変更の試みが行われた。シカゴ市がこの ように頻繁な変更を行わなければならなかった背景には、適正な建 物高さ制限を巡る関係者の思惑の違い、さらにはシカゴ固有の都市 構造や社会システムなどが関連しているものと予想される。

一方、建物の高層化はシカゴのみならず、今日まで世界中の都市 で行われている。わが国でも、20 世紀中盤以降、経済・建築技術の 発展と共に都市の中に高層建築を受け入れるようになってきた。そ の結果、都心部においては地価の高騰、事務所ビルの乱立による居 住人口の減少など、アメリカ型の都市問題が顕著となっており、問 題の解決にあたり、主にアメリカの例を参考に各種ルールの制定 · 改善が行われている。しかし、これまでのところアメリカにおける 高層建築物規制の変遷とその社会背景について、その原点から現代 に至るまでの体系的な流れがほとんど明らかになっていないために、
歴史から得られる教訓を生かし難い状況にある。

そこで、筆者たちは一連の研究の中で、アメリカにおける高層建 築物の規制と、それらを取り巻いてきた社会背景に関して、近代か ら現代までの変遷を体系的に明らかにしょうと考えた。そして、こ れらの研究を通じ、高層建築物に起因する都市問題、規制の立案過 程における関係者の影響力と利害関係、ならびに規制が及ぼした都 市の発展への影響を明らかにし、アメリカにおける高層建築物の規 制と都市整備の現実を検証することを目標とした。

今日、アメリカの多くの都市では、主に建物形態と土地利用の両 方を規制する、ソーニングにより高首建築物の規制ならびに都市整 備が行われているが、ソーニング導入以前は建物の高さ制限に代表 される、形態規制のみが存在していた。そこで、上記のような目標 に先立ち、シカゴを例に建物高さ制限がどのように成立、変遷し、 都市整備の過程で活用されていたのかを、 2 編の論文で明らかにす る事とした。第 1 編目は 2001 年 10 月に日本建築学会学術論文『1893 年シカゴの建物高さ制限の成立とその社会背景』で報告済みであり、 本稿はその続編となる 1893 年から 1902 年の 10 年間を対象とする。

アメリカ合衆国の都市の中からシカゴを選んだ理由は、1)10 年間 で 3 回の建物高さ制限の変更は、アメリカ諸都市の中でも最も多い 事例であり、それだけ形態規制のみによる都市整備の課題や問題点
* 東京大学大学院工学系研究科都市工学尃攻 大学院生.工修

** 東京大学大学院工学系研究科 教授. 工博
Graduate Student, Graduate School of Engineering, University of Tokyo, M. Eng. Prof., Department of Urban Engineering, Faculty of Engineering, University of Tokyo, Dr. Eng. 
が明らかな事例であると考えられること、2）シカゴはアメリカを代 表する都市であり、また同市が制定した建物高さ制限がアメリカの 中でも最も古いものの一つであったことから他の都市への前例とな り、影響を与えたと考えられること、そして 3)シカゴは摩天楼、す なわちスカイスクレーパーの発祥地であり、19 世紀末には世界で最 も高層建築物の建設が行われていたことから、現代にも共通する、 高首建築物が及ぼす都市の問題が顕著に表れている事例であると考 えられるからである。また、研究対象を 1893 年から 1902 年とした のは、1)シカゴ市では 1902 年の変更後、1910 年までの約 8 年間は 建物高さ制限の変更が行われず、1902 年が一つの区切りの年となる こと、2)1910 年に変更される建物高さ制限は、シカゴ市がゾーニン グ条例導入の検討を始めた際に制定されていたものであり、同条例 の検討時に影響を与えていたと考えられることから、次稿で扱うの が適当である、という理由である。

具体的に本研究では、1）実際に行われた建物高さ制限の変更と 変更の試みの内容、そして背景にあった社会問題・都市問題はどの ようなものであったか、2）変更のプロセスに誰が関わり、どのよ うな意図で変更が行われたか、そして 3） 建物高さ制限の変更が都 市に与えた影響とは何か、またこれらの変更を振り返り、都市整備 の視点からどのような課題が残ったか、について検証する。

\section{(2)これまでの研究}

これまで、アメリカの研究者による、シカゴの都市史を扱った文 献、論文は多数出版されている。代表的なものに、Harold M. Mayer and Richard C. Wade 著 Chicago-Growth of Metropolis (The University of Chicago Press, 1969) 、Perry R. Duis 著 Challenging Chicago-Coping with Everyday Life, 1837-1920 (University of Illinois Press, 1998)、そして Carl W. Condit 著 The Chicago School Architecture (The University of Chicago Press, 1964)等が あるが、参考となる建物高さ制限に関する記述は無い。一方、Carol Willis 著 Form Follows Finance (Princeton Architectural Press, 1995)、Robert Bruegmann 著 The Architects and the City (The University of Chicago Press, 1997)、そして Daniel Bluestone 著 Constructing Chicago (Yale University Press, 1991)、にはシカゴに おける建物高さ制限に関する記述がある。しかし、これらには 1893 年から 1902 年までに高さ制限が変更されていた経緯が言及されて いない。また Earle Shultz and Walter Simmons 著 Office in the Sky (The New Bobbs-Merrill Company, 1959)にはシカゴの高さ制 限の変遷についての記述があるものの、10 年間で 3 回行われた、各 変更に関する内容やそれらが行われた社会背景については言及され ていない。

\section{(3)研究の方法}

本論文は、主に 19 世紀末から 20 世紀初頭にかけて出版された新 聞、雑誌などの文献調查により、シカゴにおける建物高さ制限の変 遷とその社会背景を明らかにするものである。新聞に関しては、こ の時代に出版されたほとんどの紙面がマイクロフィルム化されてい るために今日でも入手が可能な点と、当時シカゴ市民の間で一般的 に読まれていたと考えられる点から、The Chicago Tribune 紙を主 な史料収集の対象とした。年代的には、初めてシカゴ市で建物高さ
制限が制定された 1893 年から、本研究の対象となる 1900 年代まで に焦点を当てた。なお、基本的に社説、投稿などの記事は対象とし ていないが、一部社説を引用している箇所には、(註)で「社説」と明 記する。雑誌については、当時北米で一般的であった The Inland Architects and Building News に掲載されていた 1890 年代から 1900 年代の記事を中心にシカゴの建設状況やスカイスクレーパー と都市問題、さらには建築家の意見等を参照にしている。また、建 物高さ制限を決定していたシカゴ市議会での議論を参考にするため、 市議会の議事録も調查の対象とした。これらの資料収集は主にシカ ゴ市立図書館、シカゴ歴史協会で行った。

\section{（4)当時の建物高さ制限の決定方法と他都市の制限}

19 世紀後半にはシカゴ市議会に立法などの権限が州より与えら れており、各種条例は市議会で決定できる体系が確立していた。1893 年当事、シカゴ市は 34 の区に分かれており、各区から 2 名ずつ選出 された市会議員により市議会が構成されていた。基本的に全ての条 例、もしくは条例の変更の検討は、議会内にある 20 余りの委員会(全 て 10 数名の議員で構成されている)のどれかに委託されることとな っているが、議会において、議員の全員が、緊急を要すると判断し たものに関しては委員会を通さず、直接議会で審議が行われる。条 例(案)の検討を委託された委員会は、メンバー全員の承認が得られた 段階で、条例(案)を”report”という形にして議会に戻し、議員全員の 多数決により審議を行う。賛成多数で議会を通過した条例(案)に市長 がサインをした段階で、条例は制定されるが、市長には議会の決定 を望まない場合、拒否権を発動する権利がある。建物高さ制限等の 建筑関連の条例についても、上記のプロセスを経て、議会が制定、 変更を行うが、市民に対する条例の遵守を促すのは、建築局 (Department of Buildings)である。そして建築局の責任者は建築主 事(Building Commissioner)となっている。

なお、19 世紀終盤にアメリカで建物高さ制限を制定していた都市 には、ボストン(125 フィート)1、ワシントン DC(110 フィート)2等が ある。ボストンでは州議会が、ワシントン DC では “コロンビア区 理事会” (Board of Commissioners of the District of Columbia)がそ れぞれ高さ制限の制定を行っている。

\section{2. 建物高さ制限(130 フィート)制定後のシカゴ}

1893 年にシカゴで開催されたコロンビア世界博覧会(以下、万博) の準備期間にあたる 1891 年頃のシカゴは好景気で、“Loop”(図-2) と呼ばれる中心部では、空前のスカイスクレーパーの建設ブームに より事務所スペースや小売業用の店舗等が大量に供給された。スカ イスクレーパープームは中心部への一極集中を促し、シカゴ全域の おける発展の不均衡と Loop 内の地価の高騰を招いた。これらを背景 にシカゴ市議会では、街の平面的な発展を意図する Loop の周辺と郊 外部の出身の議員たちが連携し、1893 年 3 月に 130 フィート（10 階建て）の高さ制限条例を通過させた。新聞報道の多くは、130 フ ィートの制限を歓迎しており、「条例の制定によって、シカゴ全域に わたって地価が均一化される傾向となることは疑う余地が無い」3、 といった評価が多く見られた。しかし、130 フィートの高さ制限が 市議会を通過した直後から、不動産関係者の間では高さ制限により 新規の建物の建設が激減するであろうとの見方が強く、ティベロッ 
パーの多くは Loop 地区での不動産取引を見合わせた4。事実、建物 の建替えを検討していたオーナーたちは、130 フィートの建物高さ 制限によりスカイスクレーパーの建設を諦め、既存の建物の改良に 方向転換した5。改良の多くは、これまで設備機器のスペースとして しか使われていなかった地下階を賃貸のスペースとして改良するケ 一スや 6 、既存建物の上に $1 、 2$ 層程度を增築するというものであっ た。

一方、万博開催の前にシカゴの景気は後退しはじめ、万博の終了 後には明らかな不況に見舞われた。景気の落ち込みは明らかであっ たものの、1894 年初頭には事務所スペースの需要が適度にあり、事 務所の又貸しで生計を立てるブローカーも多くいた。しかし彼らの 間では「シカゴは事務所の供給過多ではないか」との声が䠪かれて いた8。新規の建設活動が止まったことと、不景気が原因で 1894 年 には投機目的で土地の取引をする業者は皆無であったとも報告され ており9、建物高さ制限制定後のシカゴの不動産市場は活発ではなか ったことが分かる。ところが、Loop 地区における土地の価値は下が らず、不況以前の価格を維持していた10。多くの土地の所有者たちが 景気の回復を待ち、土地のリースや売却に最適な時期を窥っていた ためである11。

また 1895 年頃の特筆すべきシカゴの状況として、公共交通手段 の改革が挙げられる。まずこれまで馬車が主流であった Loop 内の交 通手段は路面電車に移り変わった 12 。さらに今日 $\mathrm{EL}($ エル)と呼ばれ る高架鉄道の一つである Metropolitan Elevated が営業を開始し、 郊外部西側地区と Loop を結んだ。また South Side Electricity が路 面電車で Loop と南側郊外の住宅地区を結んだ。このように郊外地区 と Loop を結ぶ交通のネットワークが発達した結果、さらに郊外に住 宅地の開発が進み、沿線では不動産市場が活発化する地区も出てき た。一方、その頃 Loop 内を環状に走る高架鉄道 Union Elevated Loop の計画も進んでおり、シカゴの交通事情はさらに改善するもの と、市民は期待した。不動産関係者は鉄道ルートの内側では地価の 上昇が必至と考えており13、鉄道の開業前から計画のあった通りの内 側のブロックは高い評価を受けていた ${ }^{14}$ 。

3． 建物高さ制限の変更に関する議論(1895～96 年)
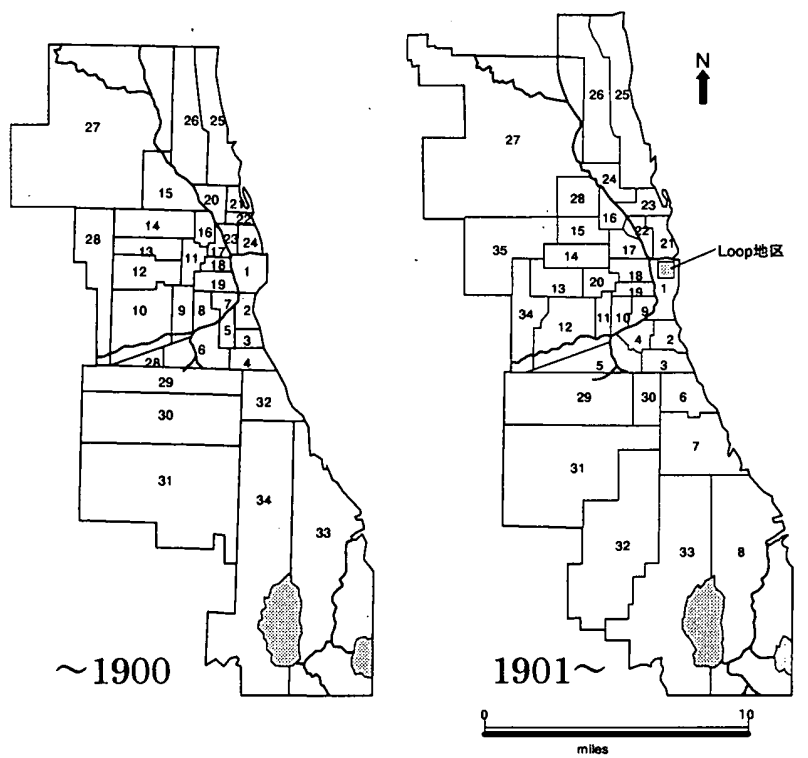

図一1 シカゴ市と区(1901 年に 34 から 35 区に增え、 区の大きさ、ナンバーリングも変更になった)

\section{(1)AIA と建物高さ制限引き上げの議論}

以上のように万博後のシカゴは、1)不況であった、2)Loop 地区の 地価は不況以前の水準を維持していた、3)130 フィートの建物高さ 制限が制定されていた、という 3 点が重なり、建物の建設が激減す るという状況にあった。この状況を改善するために行動を起こした のが建築家たちであった。

1895 年 12 月、アメリカ建築家協会イリノイ支部(以下 AIA)の定 期委員会では、建物高さ制限が議題に上った。建築家 Jenney、 Holabird らは、地価の高い Loop 地区において、収支に見合う 10 階建ての建物を建設することは不可能であるとし、130 フィートの 高さ制限が Loop の建設活動を妨げていると非難した。そして彼らは、 新築を諦めたオーナーたちにより、古くに建てられた耐火性能の低 い建物を改修、増築するケースが急增していることから、街から危 険な建物が無くならないことを問題視した。彼らは経験上、Loop 地 区において安全な耐火建築とすれば 13 階建てでは儲けがほとんど 出ないことを指摘したが、1892 年に建物高さ制限を検討した際に、 160 フィートという数値に建築家、不動産関係者等が議論して合意 した経緯を踏まえ $15 、 160$ フィートに制限を引き上げるよう市議会に 提案することとした。さらに建築家 Patton は、もし 130 フィートの 高さ制限が今後も存続するようなら、「土地所有者、借地人などの不 動産関係者が連帯し、現行の高さ制限が合法か否かを裁判で争うこ とを真剣に検討している」と新聞のインタビューに答えた16。AIA はこれらの内容を市議会に働きかけるため、建築主事(Building Commissioner)Downey との話し合いの場を設定した。

AIA の主張を踏まえ、Downey は市議会の関係者に建物高さ制限 の引き上げの必要性を説明し17、1896 年 1 月の市議会では Loop 地 区(第 1 区)の Coughlin 議員が、高さ制限を 155 フィートに引き上げ る提案を行った。Loop 周辺部の議員たちの反対はあったものの、多 数決の結果、賛成 56 対反対 11 で 155 フィートの高さ制限は市議会 を通過した ${ }^{18}$ 。

\section{(2)制限の引き上げと関係者の意見}

これに対し、シカゴ不動産協会の Birkhoff とKerfoot らは「委員 会」を結成し、Downey らと議論の場を設け、市議会の決定に反対

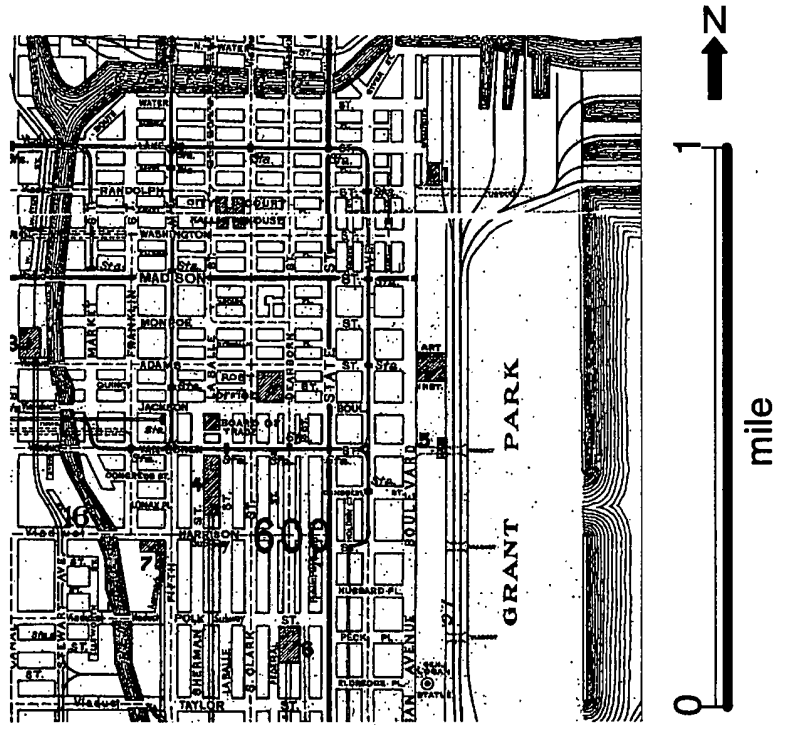

図一２Ｌoop 地区(川と湖に囲まれた、0.5 平方マイルほどの地区) 
の意向を伝えた。彼らの主張は、高さ制限を 155 フィートに引き上 げることで、1)街の中心部の混雑がより一層ひどくなる、2)130 フィ 一トの高さでも火災時に水を送り出すことが困難であるのに、新し い制限では消火活動が益々難しくなる、3)下水道のシステムが追い つかない、そして 4)あるブロックに高首建築が建設されると、その ブロック全体の地価が上昇し、他の低い建物も高い税金を納めなけ ればならなくなるために納税の平等が保てない、という 4 点から、

「街が混乱する」と言うものであった ${ }^{19}$ 。しかし、不動産関係者の中 には高さ制限の緩和により、シカゴの不動産市場が活性化するもの と期待する者も多くおり20、建物高さ制限の引き上げに反対する意見 が不動産協会の総意であったとは言い難い。

また Swift 市長は、建物高さの制限を引き上げることが街の発展 には必要であると考えており21、議会の決定が覆ることは無かった。 議事録には記録されていないが、議員の中からは、高さ制限の変更 の検討を市議会内の司法委員会等に委託すべきとの声も出たという。 しかし、シカゴの通例では「委員会」での検討には数ヶ月から半年 程度の長い期間を要するために、Swift はあくまでも議会での速やか な審議を望んだとされる22。このことは高さ制限引き上げに対する彼 の積極性を示すものと言える。

一方、スカイスクレーパーの問題には敏感な火炎保険連盟 (Chicago Underwriters Association)が、市議会の決定に反対して行 動を起こすような事態は起こらなかった。 4 年前の 1892 年にシカゴ で建物高さ制限の導入が議論されていた時、シカゴ火災保険連盟は 業界の存続の危機を回避するために、120 フィート以上の商業建築 には火炎保険の掛け金の值上げを行い、結果的に建物高さ制限の議 論に大きな影響を与えた。1 895 年当時、シカゴでは相変わらず火災 が多く発生していたものの 23 、建物オーナーの保険加入率は高く、 1896 年には中堅の保険会社の多くは黒字決算となることが確実視 されていたこともあり24、4 年前に比べ業界全体の経営状況が良かつ たことが背景にはあるものと推測される。

\section{(3)建物高さ制限引き上げ後の状況}

ところが高さ制限の緩和後から 3 ケ月が過ぎても、多くの不動産 関係者の予想とは裏腹に、シカゴに建設ブームが起こる雾囲気は無 く、不動産市場も活発化する兆しはなかった。そして 1896 年 4 月、 市議会では Loop 外の議員(第 6 区)が、早くも引き上げられたばかり の高さ制限を元の 130 フィートに引き下げる提案をした。この提案 の是非はその場では議論されず、詳細な検討は 13 名の市会議員から なる司法委員会(Committee on Judiciary)に委託されることとなっ た ${ }^{25}$ 。このケースでは、司法委員会内で 130 フィートへの引き下げ 案について委員全員の合意が得られず、議会でこの案は審議されな かったが26、制限引き下げの議論が途絶えたわけではなかった。

\section{4. 建物高さ制限の変更に関する議論 $(1897$ 年)}

(1)1897 年頃のシカゴとデパートの繁栄

1895 年から 97 年にかけて、Loop 地区では 1893 年の建物高さ制 限制定以前に建築許可を取得したスカイスクレーパーが次々と完成 する。代表的妨ものには、Fort Dearborn building(1895, 16 階建て)、 Marquette building(1895, 17 階建 $)($ 図-3)、Great Northern Office and Theater building(1895, 17 階建 $\tau$ )、Fisher building(1896, 18 階建て)、Trude building(1897, 16 階建て)等があ るが、これらは近代的な設備と快適性を売り物とした。

シカゴは先の見えない不景気の真っ只中にあったが、1897年初に は保険会社の合併が頻繁に行われていたこともあり新規のオフィス の需要は少なくなかった27。そのため、これらの竣工後間もない近代 的な建物はテナントで埋まったが、古い建物の多くは多量の空き部 屋が見られた28。後者のオーナーたちはテナントを確保するために、 貢料の值引きや建物設備、そして内外装の改良にかなりの出費を強 いられており、篇しい時代であった ${ }^{29}$ 。

さらに不景気によりシカゴでは社債や株の市場が低迷していた。 不動産市場も取引こそ低迷していたが、Loop 地区の地価の下落は無 く、ほほ景気低迷前の水準を維持していた ${ }^{30}$ 。不動産の取り引きが行 われ難かった背景には、1)土地のオーナーたちは商況が回復すれば、 土地の需要が高まり、不動産市場が活発化すると確信していたこと、 2)しかし不動産ブローカーたちは、不景気で投資に対する回収が芳 しくない状況で、当時の土地の評価額が不当に高いと考えていた、 という 2 者の意見の食い違いがあった ${ }^{31}$ 。その一方で、Loop 地区と は対照的に 1897 年頃には Loop 地区の周辺部の地価は下降気味であ った。その原因の一つが Loop 地区内の State 通りにおけるデパート の発展にあった。

State 通りには、1870 年代以降、Carson, Pirie \& Company、Fair、 Mandel Brothers、そして Marshall Field \& Company に代表され る大型のデパートが 次々と建設されていた。Fair(図一4)や Marshall Field \& Company 等はその後、増筑を繰り返し、1890 年 前半までにはそれぞれブロックの半分近くを占めるほど巨大化した。 これらのデパートは新聞広告を使った「バーゲン」を売り物とし、

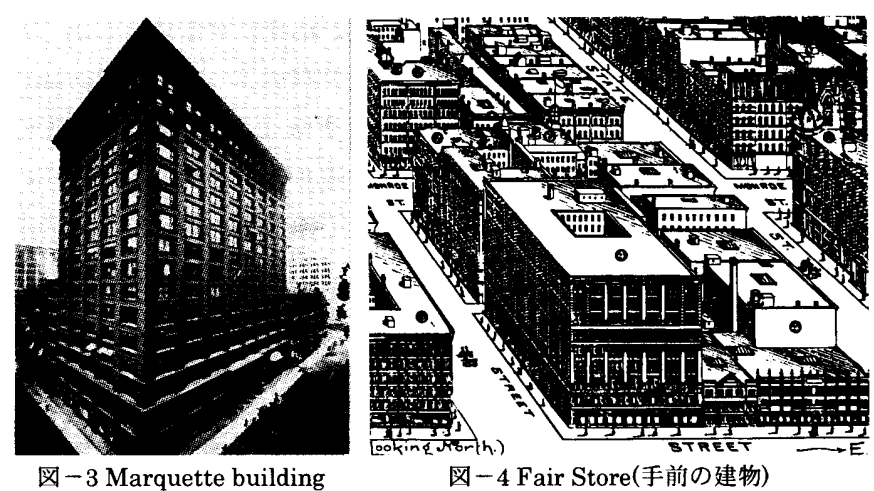

図 -3 Marquette building

四-4 Fair Store(手前の建物)

小売店舖にとって劦威となっていたが、前述のような路面電車、高 架鉄道に代表される市内全体の交通網の発達がこれらの店舖にとつ て大きな打撃となっていた。つまり、郊外に形成されていた多くの 高級住宅街は、容易に Loop にアクセスできるようになり、買い物客 は Cottage Grove 通り(図-1の第 3、4 区)、Madison 通り(同 18 区) 等の Loop 西側の周辺地区に古くからあった商店街を通過し32、デパ ート街に集中したのである。したがって、テパートに顧客を奪われ た店舗は次々と閉店を余儀なくされた。またこれらの地区にはイタ リア、ポーランド、ロシア系ユダヤ人等移民のコロニーや黒人の共 同住宅が多くあった事から、"color belt”と㭔ばれており、郊外の住 宅街とは一線を画していた。閉店後の店舗は空き家となるものも多 く、地区全体が衰退する傾向にあったことから、地価は下がった ${ }^{33}$ 。 このような状況の 1897 年には Fair が 1870 年代に建てられた店舗 部分を全面的に取り壊し、延べ面積 677,500 平方フィート、9 階建 
ての建物を増築し始めた。Fair は翌年には「世界で最大のテパート」 のタイトルを得、さらに集客力を強化した。

(2)デパート問題と建物高さ制限の引き下げ

1897 年 2 月の議会では、デパートの問題が議論された。Finkler 議員(第 26 区)は、デパートに集客力のある小売業者がテナントとし て集中することを防ぐため、デパートの出店が市議会の許可なしに はできない事とする法案を市として起草し、州議会に提出するよう 要求した ${ }^{34}$ 。の要求は賛成多数で議会を通過した。彼は説明の中で、 Loop 地区に巨大なデパートがあるために、1）シカゴ市全域にわた り小店舗が廃業に追いやられている、2）商いが数人の手で牛耳られ ている、3）1の結果として Loop から離れた地区の地価が下落して いる、そして 4）失業者が增加の一歩をたどっている、といった事 実を述べた ${ }^{35}$ 。続けて Doeer 議員（5区）は、建物高さ制限を 155 フィートから 130 フィートに引き下げる提案をした。この提案に対 し、慎重な検討を要するとして司法委員会への委託を求める声も出 たが、Doeer は高さ制限引き下げの緊急性を訴え、あくまでも議会 での審議を主張した。そして多数決の結果、58 対 2 の賛成多数で Doeer 案が議会を通過した36。Loop 地区の議員たちまでもが高さ制 限の引き下げの賛成側に回るほど、デパートの問題は市全体の大き な問題であったようである。Fair は 9 階建てであったが、元々 17 階 建てで計画されており(図一5) ${ }^{37}$ 、現行の建物の上に增築をすればさ らに床面積を增やす事が可能であった。しかし建物高さ制限の引き 下げにより、その機会はひとまずは無くなった。

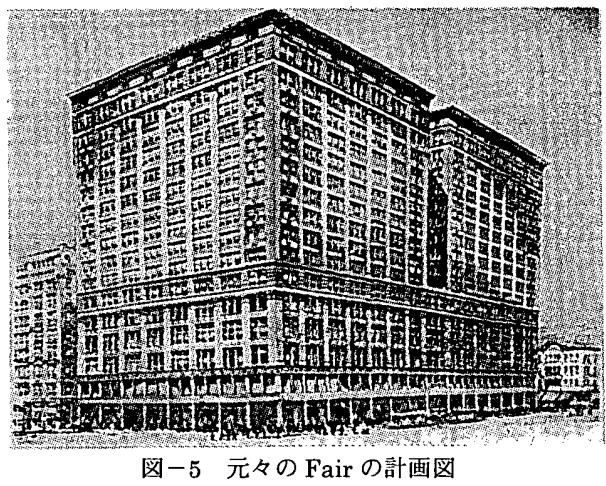

ところが 1 週間後の議会で、先の議会を欠席していた司法委員会 (Committee on Judiciary)委員長の Judah 議員（3区）は、高さ制 限を 130 フィートに引き下げることとした議会の決定に異議を申し 立て、審議のやり直しを申し入れた 38 。そして同議員の提案により、 高さ制限の 130 フィートへの引き下げ案は司法委員会で検討される 事となり、この件は落ち着いたかに見えた。しかし、翌 3 月の議会 で、再び Doerr 議員（5 区）は高さ制限の引き下げについての議論 を持ち出し、今度は 110 フィートへの高さ制限引き下げを提案した 39 。 この案は司法委員会ではなく、議会で審議される事となったが、 Campbell 議員(第 12 区)はさらに低い 90 フィートへの引き下げを提 案した。その場でこの提案を無効にする要求が複数の議員から出さ れたが、要求は通らず、高さ制限を 90 フィートに引き下げる案が審 議され、Loop 地区やその北側の地区出身の議員たちの反対を押し切 り、46 対 18 の賛成多数で市議会を通過した 40 。90 フィート案に賛 成した議員たちは、Loop 地区の高層デパートが周辺地区の商店を廃 業に追い込んでいることから、この傾向に歯止めをかけるために建
物高さ制限の引き下げはやむを得ないと、90 フィート案の正当性を 主張した 4 。

しかしこの議会の決定に対し、Swift 市長は拒否権を行使し、以 下の理由書を議会に提出した。「1896 年 1 月、それまでの高さ制限 条例を改め、高さの最高を 155 フィートに引き上げる案が議会を通 過し、私は改正案にサインをした。この改正案は高さの変更に対す るあらゆる影響を入念に調查した結果決められたものであり、また 建築局(Department of Buildings)も認めたものであることから、継 続すべきものであると考える。私の判断では、今回案(最高高さ 90 フィート)は不当に低い制限を課した理不尽なものであるため、認め ることができない」42。この市長の拒否権行使により、高さ制限に関 する議論が振り出しに戻された。すなわち、制限に関する検討は再 び司法委員会預かりとなり、155 フィートの高さ制限が復活するこ ととなったのである。

90 フィートの高さ制限が市議会を通過するという情報を得たデ イベロッパーの何人かは、それ以前の高さ制限で建物の建築許可を 取得しようと、急いでプランを建築局に提出した。その結果、少な くとも 9 棟の 12 から 14 階建ての建物に許可が下りた43。しかし、 市長の拒否権行使により制限は無効となったために、建築許可の取 得を急ぐ必要は無く、これらが実際に建設されたかも定かではない。

5. 建物高さ制限の変更に関する議論(1898 年)

(1) 1898 年頃のシカゴの状況

20 世紀が終わりに近づくにつれ、シカゴは長らく続いた不況の トンネルを脱しようとしていた。1898 年初にはシカゴにおけるほと んどの産業が活性化していたため44、多くの不動産業者が不動産市場 の活発化を予想していた。さらに資金調達の安易さ、さらに建設資 材の值下げも加わり 45、シカゴにおける建設、不動産のブームを予感 させる材料は整った。しかし、不動産市場はなかなか活発化しなか った。その原因は Loop 地区の多くの土地所有者たちが地価の上昇を 待ち、取引を行わなかったからである46。彼らは「景気の落ち込みが 大きいほど、景気回復時の反発がより大きい」として、不動産価值 は不景気以前の水準ではなく、その倍に跳ね上がると信じていた 47 。 そのため、155 フィートの制限一杯に建てても、Loop 内で収支に合 う建物の計画は難しく、1897 年の一年間に投機目的で計画、建設さ れた建物は無かうたとされている48。

\section{(2)高さ制限の引き下げと市議会での議論}

このような状況下の 1898 年の初旬、シカゴ市では建築条例全般 の見直しを図ることとなり、同年 2 月、建築局は見直すべき点を修 正した建築条例(案)を議会に提出した 49 。そして、建築局の案を審議 するため、翌 3 月に臨時の議会が召集された。条例案の中で建物高 さ制限は 155 フィートのままであったが、審議の過程で Loop 地区 の西隣、第 18 区出身である Brennan 議員は 130 フィートへの引き 下げを提案した 50 。第 27 区の Kimbell 議員は Brennan の案をその 場で無効にしようと提案したが、多数決の結果、議会の賛同を得る ことは出来なかった。建築主事 Downey も建物の最高高さは130 フ イートで十分だとする意見を述べ51、その後 Brennan の案に対する 多数決がとられた。その結果、42 対 4 の賛成多数で高さ制限は 130 フィートに引き下げられる事となった 52 。引き下げに反対した 4 名は、 
Loop の南側に位置する第 2 区の議員と郊外の議員で、Loop 地区（1 区）の議員 2 名は議会を欠席していたため議論には加わっていなか った。この時、市長は先に高さ制限の引き下げに拒否権を発動した Swift から Harrison に代わっており、市議会の決定には快くサイン をした。この議会の決定を受け、高さ制限引き下げの前の 155 フィ 一トで建物を建てようとしたオーナーが続出したため、建築許可の 件数は大きく增えた 53 。市議会の決定に対し、建築家や建設業界が反 対を表明したが54、彼らの反対も議会の決定の前には無力であった。

\section{6. 建物高さ制限の変更に関する議論(1901 から 02 年)}

(1)19 世紀末のシカゴの状況

「1899 年はあらゆる可能性と希望に満ちた幕開けとなり、産業の 水準は 1892 年以来 6 年ぶりの好況になることは間違いない」55とい った内容の記事が連日シカゴ中の新聞、雑誌で報じていたように、 20 世紀初頭、シカゴの好況は誰の目にも明らかであった。建設会社 は建設労動者のストライキによる問題を抱えていたが56、例えば郊外 地区を走る”Alley EL”と呼ばれる高架鉄道沿いではアパートの建設 がブームとなるなど、主に住宅の需要が大きかったことから建設量 自体は前年より伸びていた。不動産関係者たちは「底まで達した不 動産市場は既に上向いている」57と確信し、不動産市場もじきに活発 化すると予測していた。

\section{(2) 175 フィートの高さ制限案と市議会}

このような状況の 1901 年 1 月の市議会で、Mavor 議員(第 6 区) は建物高さ制限を 130 フ.イートから 175 フィートに引き上げる提案 を行い、案は司法委員会で検討される事となった 58 。Mavor は南側 に位置する Loop 周辺地区の出身であったが、1898 年 3 月に高さ制 限が 130 フィートへ引き下げられた際に、反対を表明していた議員 の一人であった。彼は提案を行うにあたり、「(Loop 地区で) 10 階建 てが収支に見合わないことは誰もが知っている事実だ。10階建ての 制限は間違いだ」と主張したが、この提案は 12 階建て(高さ 173 フ イート)で共同住宅を計画していた Congress Apartment Company が同議員に衝きかけたものであった59。

これまでの議論と同様に、175 フィートの高さ制限に関する関係 者の評価は大きく分かれた。不動産業界内では、Loop に拠点を持つ ディベロッパーとそれ以外のディベロッパーたちの間では意見が二 分され、シカゴ不動産協会の有力ディベロッパーである Adlis、 Smith 等は制限の引き上げに賛成したが、会長の Dietrich は、街の Loop 地区周辺への拡散を考えれば 10 階建てでも十分に高いと主張 し、175フィートの高さ制限に強く反対した 60 。

半年後の 6 月、高さ制限の 175 フィートへの引き上げ案は、司法 委員会において委員全員の合意が取れたため、"report"として議会に 提出された。しかし、案は、翌 7 月に議会で番議された結果、25 対 43 の反対多数により却下された 61 。多数決で賛成したのは Loop 地 区の議員や、司法委員会のメンバー、そしてスカイスクレーパー建 設による直接の影響を受けない郊外地区の議員数名であったが、 Loop の周辺と西側の区出身の議員たち、さらには制限の引き上げに 合意したぼ゙の司法委員会の議員数名が反対側に回り、数で賛成派 を上回った。
(3)260フィートの建物高さ制限案と市議会

1900 年頃に見られた、Loop 地区における事務所ビルの空き部屋 は 1902 年までにほぼ無くなっていた 62 。よって新しい事務所の需要 は日々高くなっていたが、地価の高い Loop 地区では、130 フィート の建物高さ制限は事務所ビルの建設を妨げる要因となっていた。そ こで、ディベロッパーの何人かは条例の放棄権を行使するために市 議会に嘆願書を提出し、高さ 130 フィートを超える建物の特別許可 を要求し始めた。特別許可を求めたのは、どれも Loop 地区に事務所 の新築や増築を計画していたディベロッパーたちで、16 階建てが 7 棟、 14 階建てが 1 棟の計 8 棟であった。しかし、主に Loop 周辺地 区出身の議員が反対し、許可は保留された63。

特別許可申請の実態を受けて、市議会では建物高さ制限の変更に 関する議論の場が設けられた。そこでまず、Ebemann 議員(第 24 区) が建物高さ制限を 130 フィートから 260 フィートに引き上げるよう 提案した64。しかし、これに対し Conlon 議員(第 18 区)は案の取り消 しを提案し、多数決の結果 260 フィート案は却下された。続いて、 Eidmann 議員(第 32 区)は 175 フィートの高さ制限を提案したが、 Jackson議員(第3区)の反対により取り消された。次にAlling 議員(第 2 区)は 275 フィートの制限を、Jackson 議員（第 3 区）は 261 フィー トの制限を、をそれぞれ提案したが、多数決により却下された。高 さ制限の引き上げ賛成派と反対派はどちらも譲らず、議論は収まる 様相に無かった。

そこで、Carey 議員(第 29 区)は耐火構造ではない建物には従来の 130 フィートの高さ制限を、耐火建築物に対しては高さの制限の撤 廃を提案した65。議会ではこの案に対する是非で議論の決着をつける 事となり、多数決の前に各議員が意見を述べた。案に反対する議員 からは、高さ制限を撤廃すれば結果として、シカゴ市民を「金持ち と貧困者」に二分するとする意見や、巨大なデパートが Loop 内に建 設されかねないとする意見があった。しかし、Goldzier 議員(第 21 区)は制限の撤廃に賛成で、「(高さ制限により)企業の活動を邪魔す ることは全くのナンセンスだ。市会議員はこれまでの経験から、ス カイスクレーパーがもたらすとされる街への影響についての古い理 論が成り立たないことを認識すべきだ」と述べ、Palmer 議員（第 21 区）も市議会が各地区の不動産価値を左右するような規則の決定を 行う権利はない66、と制限の撤廃に賛成した。各議員が意見を一通り 述べたところで、多数決が採られ、56 対 9 の賛成多数で、耐火構造 以外の建築物は高さの最高を 130 フィートに、耐火構造の建築物は 高さを無制限にすることが決定した67。

この議会の決定を多くの関係者が支持した。まず、建物高さ制限 の撤廃による建設ブームを見込んでいた建設業界や、それに伴い不 動産ブームを予想していた不動産業界が制限の撤廃を歓迎した。直 ちに建設許可が下りる、8 棟のスカイスクレーパーの建設費は合計 $20,000,000$ ドルに上ると見られており、シカゴ史上最大の建設ブー ムと言われた 68 。そのうち $15,000,000$ ドルが建設労働者の賃金にあ たり、向こう 2 年間は労働組合との問題が鎮静化するものと、建設 業界関係者は期待した 69 。

さらに、The Chicago Tribune などのメディアも市議会の決定を 歓迎した。同紙の社説によれば、都市におけるスカイスクレーパー の最大の貢献は、1世代前には「耐火建築物」と称されていた「不 良建築」を駆逐することであった 70 。すなわち、不良建築が中空夕イ 
ル、テラコッタ、そしてコンクリートといった材料をふんだんに使 用し、避難階段、消火栓等の器具を設置した「優良建築」に取って 代わり、街の安全度が増すことから、スカイスクレーパー建設の推 進は公共の利益となる、という理論である。

そして、制限の撤廃が市民の話題となっていた頃、偶然にもスカ イスクレーパーの安全性を証明するような事件が起きた。1902 年 2 月の早朝、Loop 地区の主要な通りである Randolph 通り沿いにあっ た 5 階建てのビルから出火し、消火活動が行われるまでに火は勢い を增した。ところが、16 階建ての耐火建築物である Trude Building が隣接していたために、火はブロック全体に広がる前に消し止めら れたのである。現場に駆けつけた消防局長は、もし、出火した建物 に Trude Building が隣接していなかったら、「我々はブロック全体 を守ることはできなかったであろう」と説明し、「ダウンタウンか ら"fire traps"(燃えやすい建物)が耐火建築に取って代わらない限り、 1871 年の大火の惨劇はいつ起きてもおかしくない」71と述べ、シカ ゴ市民を驚かせた。この事件で、近代的なスカイスクレーパーはそ れら自体が耐火構造であるだけでなく、他の建物からの火災の延焼 も食い止めることも実証した。

一方、街の景観、衛生、そして交通問題等に対し、スカイスクレ 一パーが及ぼすマイナス要因を指摘する声もあったため、The Chicago Tribune 紙は社説の中で独自の論を展開している72。まずス カイスクレーパーが街のスカイラインを壊すという意見に対し、同 紙は仮に今よりも高くとも、ブロック全体に高さの近いスカイスク レーパーが建ち並べば、スカイラインは統一されるので大きな問題 とはならない、とした。また道路への日照等の衛生の問題に関して は、1)シカゴは新しい街のため道路の幅員が広いので日照は確保さ れる、2)収支を考慮すると、スカイスクレーパーは一等地である角 地に建設されることが多く、ブロックの内部には道路から日照を完 全に奪うほど高い建物は多く建設されない、そして 3)シカゴは強風 の街であり、スカイスクレーパーによって通りの通風が妨げられる ことはない、との見解を示した。

このようにして、不動産業界や建設業界、そしてシカゴで最も影 響力のあるメディアも含め、耐火建築物の高さ制限を撤廃するとし た市議会の決定を支持する意見が多く聞こえた。しかし、市長は市 議会の決定に関して修正が必要であると主張し、次のようなコメン トを公式に発表した。「関係者の多くは高さ制限の撤廃を望んでは いないと思われ、公共の安全と商業関連の利益の両方を考慮して、 完全耐火の建築物に対し 16 階建て、260フィートの高さ制限を定め れば、関係者の合意を得ることはやさしいと私は確信する」 73 。

この市長のコメントから 1 週間後の 1902 年 2 月 24 日に開催され た市議会で、260 フィートの高さ制限は審議され、43 対 13 の賛成 多数で議会を通過、制定された74。

(4)建物高さ制限の引き上げ後の都市

関係者の予想通り、建物高さ制限が大幅に引き上げられたため、 Loop 内ではスカイスクレーパーの建設ブームが起き、不動産取引も 活発化した。最も顕著であったのが、State 通りである。同通りの地 価は 1904 年頃には「ここ数年前までは想像すらしなかったレベル」 にまで達し、1906 年には「この世に State 通りの土地以上に高価な ものは存在しない」とさえ言われた75。また Loop 地区全体の事務所
スペースの貨料も 1902 年の 1 年間で $15 \%$ 上昇し、1903 年 1 年間に はさらに $15 \%$ 上昇した。

さらに、景気の状況が極めて好調であったことから、関係者の間 では Loop 地区のみならず、郊外地区、例えば North Shore、West Side と言った北、西側の地区や 南側の Calumetなどの地区でも不 動産ブームが波及するであろうとの予測がされた76。確かに、住宅地 として人気の高かった North Shore、水運を利用し、嵘物、鉄鋼等 の基地として発展した Calumetなどに代表される郊外地区では、全 体としての地価は上昇した。一方、工場や移民等の共同住宅が混成 していた Loop 周辺地区では、移民の增加に伴い、各民族のコロニー の拡大や、工場の郊外への移転が行われていた。その結果、同地区 の地価の下落傾向は続いた77。

一方、建設ブームとなった 1900 年代以降、Loop 地区の混雑はさ らにエスカレートする傾向にあり、多くの者が交通混雑の畺化がス カイスクレーパーに起因する、と指摘した78。そして、市の警祭局で も交通混雑の問題は「最も深刻な問題」と考えられていたことから、 多数の検討会議の場が持たれていた。しかし、抜本的な解決策は見 出されず、1910 年代においてもこの状況は変わらなかった。

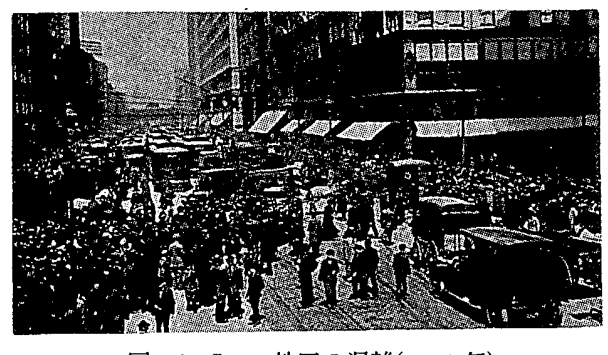

図-6 Loop 地区の混雑(1910 年)

6. まとめ

本研究では、以下の三点が明らかとなった。

(1)シカゴにおける都市問題と建物高さ制限の変更

20 世紀初頭における、シカゴ市の最も逼迫した都市問題とは、中 心部の Loop 地区とその周辺地区、そして郊外の発展の格差であった。 この発展の格差を解消するためには、街が平面的に発展する必要が あり、Loop 周辺地区の議員たちは、なるべく低い建物高さ制限の制 定を望んだ。一方、Loop の地価は不況下にも下がることは無く、Loop 内で開発を計画する者にとって、高さ制限は高い方が有利であった。 つまり、この両者の対立が制限の変更の背景にあった。

しかし、このような発展の格差は、ビジネス街として発展してい た Loop 地区がその三方を湖と川で囲まれているという、シカゴ固有 の地理的条件に起因していた。また Loop 周辺地区の地価の下落は、 同地区に color belt と呼ばれていた移民の人々の住居地区が形成さ れていたことや、市内の交通網が急速に発展した結果、Loop と郊外 地区のアクセスが格段に良くなり、郊外に住宅街や工場地帯が急速 に発展したこと、さらにはLoop 地区内のデパート街がさらに活性化 した結果、周辺地区の商店が閉鎖を余儀なくされた、といった複数 の要因が背景にあった。したがって、Loop 周辺地区も含めたシカゴ 全体の発展を建物高さ制限のみによってコントロールする、という ことは極めて困難であり、実際に制限を引き下げても明らかな周辺 地区発展の効果は見られなかった。

(2)建物高さ制限をめぐる市議会における議論 
特筆すべき事実として、1900 年代に行われた、高さ制限の大幅な 引き上げや撤廃の提案は、全てスカイスクレーパーの需要が高くな い Loop 周辺地区出身の議員たちによって行われたことが挙げられ る。例えば、1901 年に制限の 175 フィートへの引き上げ案が持ち上 がった際には、Loop でスカイスクレーパーを計画していたティベロ ッパーが、第 6 区の議員に働きかけを行っていた。その際、同議員 とティベロッパーの間で金銭の授受があったかどうが明らかでな いが、この例は議員自身が属する地区の発展とは直接的には結びつ かないケースで、制限の変更が提案されていたことを示すものであ る。同様に、制限の変更を望む者が、その変更によって直接的な影 響を受けない地区の議員に対し、何らかの㗢きかけを行ない、賛成 の票を確保することができた可能性は大いにある79。

実際、一連の変更を通じ、Loop 地区の議員は高い建物高さ制限を、 Loop 周辺地区の議員は低い制限を望むという傾向は見られたもの の、郊外部出身の議員のように、どちらの側をとるか明確な傾向を 持たない議員も多くいたことが分かった。このことは、例えば 1901 年に出された高さ制限の 175 フィートへの引き上げ案に対し、西側 郊外地区のほとんどの議員が反対していたにもかかわらず、1902 年 に制限の撤廃に関する議論が行われた際、一転して彼らの多くが賛 成側に回っていたケースなどで確認できる。このように、議員の多 くはスカイスクレーパーに対し一貫した考えを持っておらず、議会 内での制限の変更に関する議論はごちらに転ぶか予測しづらい状況 があった。この事は、高さ制限の変更を望む者にとっては好都合で あり、結果的にシカゴ市議会で、毎年のように制限の変更案が議論 される事となる要因であったと、言える。

\section{(3)建物高さ制限の変更の影響と都市整備上の課題}

1893 年から 1900 年頃までに行われた、130〜155 フィート間の 建物高さ制限の変更は街に大きな影響を与えなかったことが明らか となった。これは Loop 地区の地価があまりにも高く、2 層程度の制 限の緩和はディベロッパーに対して大きなメリットとはならなかっ た事が背景にある。しかし 1902 年に行われた、130 から 260 フィ 一トへの変更によりスカイスクレーパーブームとなったことから、 Loop 地区の地価の上昇、道路混雑の悪化などの街に対する影響があ った。

また 1902 年以降、State 通りには新たなデパートの建設や、 130 フィートを超える部分での既存デパートの増勧が相次ぎ、Loop 地区 への買い物客の集中が一層進んだ。20 世紀初頭時点のシカゴ市全体 を見渡すと、オフィス・デパート街の Loop、そして住宅街、工業地 帯の郊外、という地図がほほ形成された一方で、これらの中間に位 置する Loop 周辺地区が発展する材料は乏しく、関係者の不満が募っ た。今後、高さ制限だけではコントロールし得ない、同地区の発展 をどうすべきか、という都市整備上の課題が残された。

次稿では、この課題に対し、シカゴ市が出した答えとなるソーニ ング条例の成立について述べる。

(写真および図)

図-2: Perry Duis, Chicago Creating New Tradition

图 -3: Frank A. Randall, History of the Development of Building Construction in Chicago

図 4: Robert Bruegmann, The Architects and the City

図 -5: Theodore Turak, William Le Baron Jenney.

図 -6: Harold M. Mayer and Richard C. Wade, Chicago-Growth of Metropolis
(註)

1 Holleran, Michael, "Boston's 'Sacred Sky Line', “ Journal of Urban History 22, July 1996, pp. $552 \cdot 587$.

2 Staff Report for the Committee on the District of Columbia House of Representatives Ninety-fourth Congress, Building Height Limitations, U.S. Government Printing Office, pp. 15, 1976.

3 The Chicago Tribune, 12 March, 1893. pp. 30

4 The Chicago Tribune, 26 March, 1893. pp. 30 5 同上

6 The Chicago Tribune, 19 March, 1893. pp. 30

The Chicago Tribune, 29 December, 1895. pp. 28

The Chicago Tribune, 1 January, 1894. pp. 20.

The Chicago Tribune, 1 January, 1895. pp. 20.

${ }^{10}$ The Chicago Tribune, 1 December, 1895. pp. 50.

11 The Chicago Tribune, 29 December, 1895. pp. 28.

12 同上

3 同

14 The Chicago Tribune, 12 January, 1896, pp.35.

15 The Chicago Tribune, 22 December, 1895. pp. 35.

16 同上

17 The Chicago Tribune, 9 January, 1896, pp.1.

18 Proceedings of the City Council of Chicago, 1895-1896, pp. 1643

19 The Chicago Tribune, 10 January, 1896, pp. 1.

20 The Chicago Tribune, 12 January, 1896. pp. 35.

${ }_{21}$ Proceedings of the City Council of Chicago, 1896-1897, pp.1769-1770.

22 The American Architect and Building News, 29 February, 1896, pp.99.

1893 年に発生した火災は計 5224 件、1894 年は計 5174 件、そして 1895 年は計 5316 件と記録されている。Report of the Fire Marshal to the Common Council of the City of Chicago, 1894, pp. 103, 1895, pp.86

24 The Chicago Tribune, 1 January, $1896 \mathrm{pp} .22$.

25 Proceeding of the City Council of Chicago, 1896-1897, pp. 62.

26 Proceeding of the City Council of Chicago, 1896-1897, pp. 123.

27 The Chicago Tribune, 28 February, 1897. pp. 50.

28 同上

29 覒料の水準は Loop に位置する平均的な事務所ビルで、1895 年には 1.75 ド ル/平方フィートであったものが、1896年には1.40ドルに、1897年には

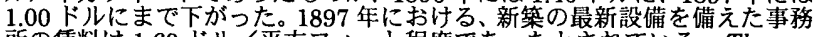
所の賁料は 1.60 ドル/平方フィート程度であったとされている。The Chicago Tribune, 21 March, 1897, pp. 48.

30 The Chicago Tribune, 29 August, 1897 . pp. 34.

31 The Chicago Tribune, 21 March, 1897, p.48.

32 Hoyt, Homer, One Hundred Years of Land Values in Chicago, The University of Illinois Press, pp. 192, 1931.

The Chicago Tribune, 29 August, 1897. pp. 34

The Chicago Tribune, 9 February, 1897, pp. 7.

Proceedings of the City Council of Chicago, 1896-1897, pp.1549. "The Chicago Construction, or Tall Buildings on a Compressible Soil," The American Architect and Building News, 16 April, 1892, pp. 45.

38 Proceedings of the City Council of Chicago, 1896-1897, pp.1569.

39 Proceedings of the City Council of Chicago, 1896-1897, pp.1731-32. 同上

1 The Chicago Tribune, 9 March, 1897, pp.2.

42 Proceedings of the City Council of Chicago, 1896-1897, pp.1769-70.

43 The Chicago Tribune, 14 March, 1897, 16 March, 1897, pp. 7.

${ }_{44}$ The Chicago Tribune, 2 January, 1898. pp. 23.

45 京上

46 The Chicago Tribune, 30 January, 1898. pp. 34

47 The Chicago Tribune, 2 January, 1898. pp. 23.

48 The American Architect and Building News, 15 January, 1898, pp. 23.

49 Proceedings of the City Council of Chicago, $1897 \cdot 1898$, pp. 1770.

Proceedings of the City Council of Chicago, 1897-1898, pp. 2006-2007.

The Chicago Tribune, March 24, 1898, pp.12.

2 Proceedings of the City Council of Chicago, 1897-1898, pp. $2006 \cdot 2007$

The Chicago Tribune, 3 April, 1898. pp. 38.

${ }^{4}$ The Chicago Tribune, 27 March, 1898, p. 38. The Chicago Tribune, 25 March, 1898, p. 10.

5 "Building Outlook," The Inland Architect and News Record, January 1899, vol. xxxii, pp.60

56 The Chicago Tribune, 17 June, 1901. pp. 12.

57 The Chicago Tribune, 22 June, 1901.pp. 29.

58 Proceedings of the City Council of Chicago, 1901·1902, pp. 407

59 The Chicago Tribune, 11 June, 1901, pp. 8 .

60 The Chicago Tribune, 11 June, 1901, pp. 8.

61 The Chicago Tribune, 2 July, 1901, pp.

2 Hoyt, pp. 210.

The American Architect and Building News, 8 February, 1902, pp. 48 15 February, 1902, pp.49.

64 Proceedings of the City Council of Chicago: 1901-1902, pp.2005·2007.

65 同上

66 The Chicago Tribune, 4 February, 1902, pp. 1.

67 Proceedings of the City Council of Chicago:1901-1902, pp.2005-2007.

68 The Chicago Tribune, 5 February, 1902, pp. 7.

69 同上

70 The Chicago Tribune, 6 February, 1902, pp. 12. (社説)

71 The Chicago Tribune, 9 February, 1902, pp. 12.

72 The Chicago Tribune, 6 February, 1902, pp. 12. (社説)

${ }_{73}$ Proceedings of the City Council of Chicago: 1901-1902, pp.2027.

${ }^{74}$ Proceedings of the City Council of Chicago:1901-1902, pp.2084

Hoyt, pp. 211.

${ }_{7}$ Hoyt, pp. 217.

August Gatzert, Limitation of Building Height, City of Chicago, 1913

pp. 2 .

7920 世紀末のシカゴ市議会では賄䀩の授受が公然と行われており、一説には non·boodlers と呼ばれる賄䀩が通じない議員は68名の議員中 18 名程度し か存在しなかったと言わ机ている。詳しくは、William T. Stead, If Christ Came to Chicago(Laird \& Lee, Publishers, 1894) 